\title{
Disordered blood coagulation in burned children receiving high molecular weight dextran
}

\author{
TREVOR THOMAS, ARTHUR MORRIS, AND MICHAEL S. ROSE \\ From the Departments of Haematology and Plastic Surgery, Guy's Hospital, London
}

SYNOPSIS Coagulation studies were performed on nine children with burns. Four of these children received treatment which included intravenous dextran; all four showed abnormalities of coagulation and two of them developed a bleeding state. No abnormalities of haemostasis were detected in the remaining five children who had comparable degrees of burns but whose treatment did not include intravenous dextran.

Our attention was first drawn to a disturbance of coagulation following burns in a 2-year-old child (Table, case 1). He began to bleed profusely from the sites of injury two days after suffering a scald involving $25 \%$ of his body surface (Fig. 1). During the 48 hours following the burn fluid was administered intravenously in the form of dextran (Dextraven ${ }^{1} 110$ and 150) and half-strength Hartman's solution, as calculated from the fluid regime described in the addendum. The results of coagulation studies are shown in the Table (case 1). A diagnosis of disseminated intravascular coagulation was considered likely. At the time of the bleeding, swabs taken from the burned area showed no bacterial growth. As septicaemia is a recognized cause of disseminated intravascular coagulation, blood cultures were taken but no significant microbial growth occurred.

Heparin therapy was started by continuous intravenous infusion (100 units $/ \mathrm{kg} / \mathrm{six}$ hours). The subsequent changes are shown in Figure 2. These results are evidence that the disorder of coagulation was corrected. The bleeding stopped within 12 hours of starting heparin and the patient returned home 10 days later without requiring a skin graft. We afterwards observed that the onset of heparin therapy had coincided with the withdrawal of dextran.

Generalized spontaneous bleeding is extremely unusual as a complication of burns, except as a result of secondary infection. No reference is made to such events in current editions of standard textbooks (Sevitt, 1957; Biggs and MacFarlane, 1962; Hardisty and Ingram, 1965) or in recent symposia (Annals of the New York Academy of Sciences, 1968) or reviews

${ }^{1}$ Fisons Ltd.

Received for publication 5 January 1972.

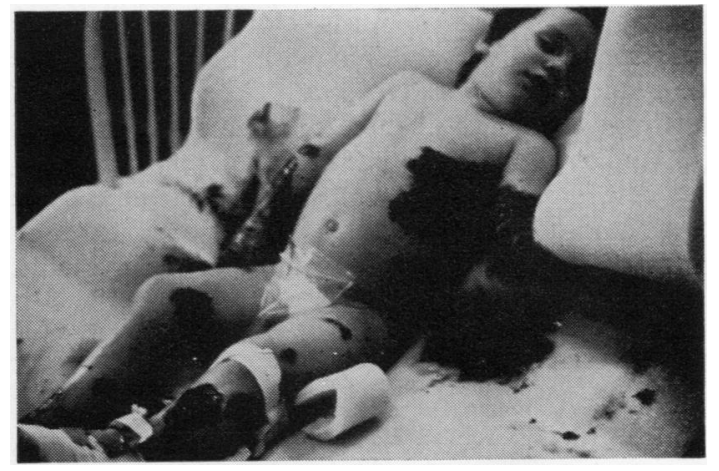

Fig. 1. Bleeding from sites of injury.

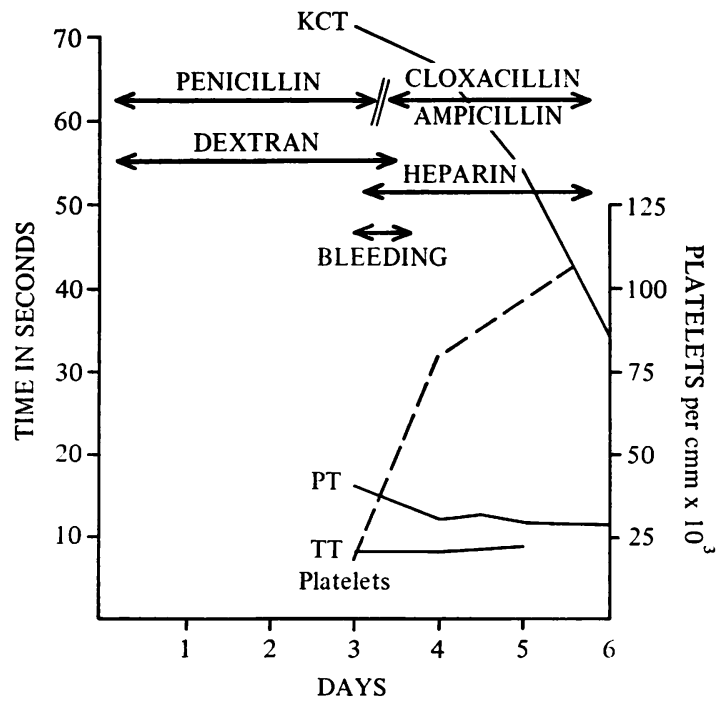

Fig. 2. Changes after heparin. 
(Pitney, 1971). The changes in coagulation factors and platelets have been studied after cutaneous burns in human subjects (MacDonald, Levenson, Davidson, Tagnon, and Taylor, 1944) and in experimental animals (Dodd-Wilson, Taylor, and Nicholson, 1965; Mazak, Vanasek, and Mateja, 1965). Shortly after an extensive burn clotting systems are accelerated (Sevitt, 1957). In subjects who die within hours or a few days of severe burns, disseminated microthrombi are frequently found. These findings may be the counterpart of a consumption coagulopathy. Nevertheless bleeding is an unusual problem in clinical experience.

In view of these observations we believe that the clinical and laboratory findings which follow may be of some interest.

\section{Coagulation Studies in Other Burned Children}

Because of the unexpected bleeding in an otherwise uncomplicated case of burns, clotting studies were performed in eight children with burns who were admitted to Guy's Hospital. Abnormalities of clotting were found in three of these children (cases 2,3 , and 5) all of whom had received dextran: case 3 bled considerably for a number of days from the site of a femoral vein puncture. No abnormalities of clotting were found in the remaining five patients, none of whom had received dextran (cases 4, 6, 7 , 8, and 9). Details are shown in the Table.

Case 4, with $13 \%$ burns, was given neither dextran nor plasma, and cases 6-9, with burns between $14 \%$ and $30 \%$, received plasma and no dextran. In case 5 , samples were tested before, during, and after the administration of dextran, and the sequence of events is illustrated in Figure 3.

In-vitro Effect of Dextran on Coagulation and Platelets

Standard coagulation tests (Hardisty and Ingram, 1965) were employed to characterize the effects in vitro of dextran upon the clotting system.

\section{METHODS}

Doubling dilutions of $6 \%$ dextran (Dextraven 110) were prepared in $5 \%$ dextrose. Each dilution was mixed with an equal part of pooled normal plasma. The diluted mixtures were tested for prothrombin time, kaolin-cephalin time, and thrombin time.

A partial thromboplastin time, without kaolin, was used as a test of activation of the contact factors. Blood was taken from normal donors and the tests were carried out in siliconized apparatus. A series of doubling dilutions of $6 \%$ dextran were prepared in $5 \%$ dextrose. Equal parts of each dilution were added to the normal plasma. Partial thromboplastin times

\begin{tabular}{|c|c|c|c|c|c|c|c|c|c|c|c|c|c|c|c|c|c|c|c|c|c|}
\hline \multirow[t]{2}{*}{$\begin{array}{l}\text { Case } \\
\text { No. }\end{array}$} & \multirow[t]{2}{*}{ Age } & \multirow[t]{2}{*}{ Sex } & \multirow{2}{*}{$\begin{array}{l}\text { Per- } \\
\text { centage } \\
\text { Area } \\
\text { Burnt }\end{array}$} & \multirow[t]{2}{*}{ Bleeding } & \multirow{2}{*}{$\begin{array}{l}\text { Intra- } \\
\text { venous } \\
\text { Fluid }\end{array}$} & \multicolumn{3}{|c|}{$\begin{array}{l}\text { Prothrombin } \\
\text { Time }^{2}\end{array}$} & \multicolumn{3}{|c|}{$\begin{array}{l}\text { Kaolin-cephalin } \\
\text { Time }^{2}\end{array}$} & \multicolumn{3}{|c|}{$\begin{array}{l}\text { Thrombin } \\
\text { Time }^{2}\end{array}$} & \multicolumn{3}{|c|}{$\begin{array}{l}\text { Fibrinogen } \\
\text { Titre }^{2}\end{array}$} & \multicolumn{3}{|c|}{$\begin{array}{c}\text { Platelet Count } \\
\times 10^{3}\end{array}$} & \multirow[t]{2}{*}{$\begin{array}{l}\text { Progress of } \\
\text { Patient }\end{array}$} \\
\hline & & & & & & 1 & 2 & 3 & 1 & 2 & 3 & $I$ & 2 & 3 & $l$ & 2 & 3 & 1 & 2 & 3 & \\
\hline 1 & 2 & $\mathbf{M}$ & 25 & Yes & $\mathbf{P}+\mathbf{D}^{1}$ & & 17 & 13 & & 70 & 35 & & 8 & 9 & & 16 & 64 & & 17 & 125 & $\begin{array}{l}\text { Recovered; } \\
\text { no graft }\end{array}$ \\
\hline 2 & $4 \frac{1}{2}$ & $\mathrm{~F}$ & 20 & No & D & & 15 & 13 & & 120 & 45 & & 8 & $7 \cdot 5$ & & 32 & 128 & & 100 & 100 & $\begin{array}{l}\text { Recovered; } \\
\text { split skin } \\
\text { grafts }\end{array}$ \\
\hline 3 & 2 & $\mathbf{F}$ & 40 & Yes & $\mathrm{D}$ & & 20 & 25 & & 64 & 100 & & $7 \cdot 5$ & 11 & & 64 & 16 & & 140 & 45 & $\begin{array}{l}\text { Died of } \\
\text { respiratory } \\
\text { burns }\end{array}$ \\
\hline 4 & $9 / 12$ & $\mathbf{M}$ & 13 & No & 一 & 14 & & & 30 & & & 14 & & & & & & & & & $\begin{array}{l}\text { Recovered; } \\
\text { no grafts }\end{array}$ \\
\hline 5 & 9 & $\mathbf{F}$ & 17 & No & D & 13 & 14 & 14 & 30 & 68 & 55 & 13 & 7 & 9 & 128 & 64 & 64 & 130 & 45 & 150 & $\begin{array}{l}\text { Recovered; } \\
\text { no grafts }\end{array}$ \\
\hline 6 & $8 / 12$ & $\mathbf{M}$ & 15 & No & $\mathbf{P}$ & 13 & 13 & & 33 & 33 & & 12 & 10 & & & 64 & & 201 & 252 & & $\begin{array}{l}\text { Recovered; } \\
\text { split skin } \\
\text { grafts }\end{array}$ \\
\hline 7 & $8 / 12$ & $\mathbf{M}$ & 16 & No & $\mathbf{P}$ & 14 & 14 & & 28 & 37 & & 12 & 16 & & 128 & 64 & & 324 & 151 & & $\begin{array}{l}\text { Recovered; } \\
\text { no skin } \\
\text { grafts }\end{array}$ \\
\hline 8 & 3 & $\mathbf{M}$ & 30 & No & $\mathbf{P}$ & 13 & 14 & & 31 & 36 & & 11 & 13 & & & 128 & & 189 & 343 & & $\begin{array}{l}\text { Recovered; } \\
\text { split skin } \\
\text { grafts }\end{array}$ \\
\hline 9 & 2 & $\mathbf{M}$ & 14 & No & $P$ & 13 & 14 & & 27 & 39 & & 11 & 11 & & & & & & & & $\begin{array}{l}\text { Recovered; } \\
\text { no skin } \\
\text { grafts }\end{array}$ \\
\hline \multicolumn{6}{|c|}{ Control figures } & \multicolumn{3}{|c|}{$13-14$} & \multicolumn{3}{|c|}{$32-37$} & \multicolumn{3}{|c|}{$11-14$} & \multicolumn{3}{|c|}{$64-$} & \multicolumn{3}{|c|}{$200-400$} & \\
\hline
\end{tabular}

Table Clinical and laboratory details of children with cutaneous burns

${ }^{1} \mathrm{D}=$ dextran, $\mathbf{P}=$ plasma

21, 2, 3 denotes: 1 , sample taken before intravenous therapy commenced; 2 , sample taken during intravenous therapy; 3 , sample taken 24 hours ${ }^{2}$ after conclusion of intravenous therapy. 


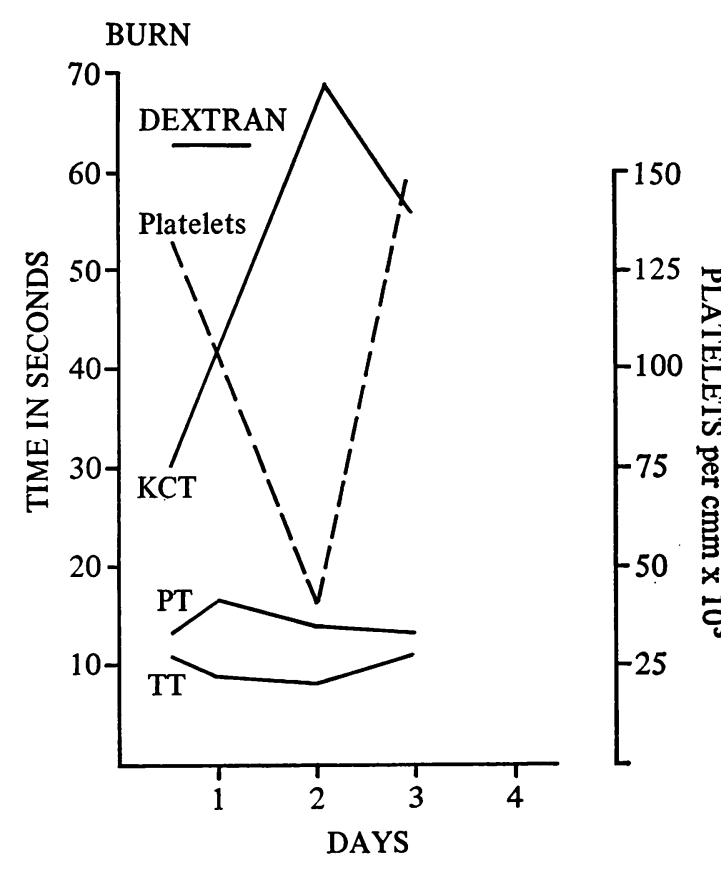

Fig. 3. Sequence of events in case 5 after dextran.

were then measured in these mixtures. Control measurements were made upon plasma-dextrose mixtures.

The aggregating effects of dextran on platelets were studied by mixing platelet-rich plasma in equal parts with dilutions of dextran in dextrose. Samples were incubated for 30 minutes at $37^{\circ} \mathrm{C}$. They were then examined microscopically.

\section{Results}

The addition of dextran was found to have no effect on the prothrombin or kaolin-cephalin times. However the addition of a $50 \%$ dextran solution was responsible for shortening the thrombin time from 12 seconds to 8 seconds.

The addition of dextran to plasma did not shorten the partial thromboplast time.

Dilutions between $12 \cdot 5$ and $50 \%$ of the $6 \%$ dextran solution caused aggregation of platelets after 30 minutes at $37^{\circ} \mathrm{C}$ whereas aggregation was not observed after incubation with dextrose.

\section{Discussion}

Dextran preparations are widely employed in the early treatment of severe burns with fluids. A limited enquiry from burns units in the vicinity of London has made it clear that bleeding problems in subjects receiving dextran have not been encountered. But although the laboratory findings described above could have been a consequence of the burns (MacDonald et al, 1944; Johansson, 1961 and 1964; Arturson and Wallenius, 1964; Hawtof, 1966) it seems more likely that the administration of dextran produced the coagulation abnormalities and the fall in platelets. Certainly, at least, the concentration of dextran employed in the in vitro test systems corresponded closely to the in vivo dextran concentrations which were present during and shortly after colloid replacement treatment (see addendum).

The effects of dextran upon platelets and clotting factors are partly determined by its molecular size (Nilssen and Eiken, 1964). Our observations are similar to those of Dhall, Harper, McKenzie, and Matheson (1966) who demonstrated that dextrans ranging in molecular weight from 10000 to 500000 caused aggregation of human platelets in vivo. Berman (1964) showed that dextran inhibits platelet aggregation in vivo at sites of injury in the hamster cheek pouch. Others have shown that dextran infusion into healthy human subjects reduces platelet adhesiveness (Bygdeman and Eliasson, 1966; Bennett, Dhall, McKenzie, and Matheson, 1966). Possibly these discordant findings can be explained by the sequestration in vivo of clumped platelets after dextran infusion, leaving a residual circulating population of platelets with uncharacteristic activity. However, Bennett et al (1966) did not note any substantial change in the venous platelet count of their subjects within 24 hours of dextran infusion.

Bergentz, Eiken, and Nilssen (1961) found that infusion of high-molecular weight dextran into dogs caused thrombocytopenia, fibrinogenopenia, and depletion of other coagulation proteins. Heparin prevented all of these effects apart from the thrombocytopenia. If these effects of dextran represented a true consumption coagulopathy, heparin would be expected to prevent thrombocytopenia. Furthermore the rate at which the platelet count returned to normal in case 1 after heparin therapy is unusually rapid for this syndrome.

We found no evidence that dextran either inhibited or activated coagulation in vitro. However, we found a striking shortening of the 'thrombin time' both in the plasma of patients transfused with dextran and in normal plasma mixed with dextran. This 'fibrinoplastic' effect has been previously described by Laurell (1951) and Jacobaeus (1955).

Working with dogs, Nilssen and Eiken (1964) showed that the molecular weight of the dextran was the main factor in determining the degree to which coagulation was impaired. They argued that the 
administration of high molecular weight dextran causes a consumption coagulopathy. We are inclined to explain our findings as the result of independent effects of dextran upon coagulation factors and platelets. It is intriguing that dextran is responsible for a shortened thrombin time both in vivo and in vitro, and correspondingly accelerates the final steps in clot formation, whereas its other effects in vivo are inclined to produce impaired clotting. Whatever the sequence of events, it is clear that a reduction in coagulation and a fall in platelets frequently accompanies the administration of high-molecular weight dextrans.

Dextrans are widely used in the early treatment of burns and overt failure of haemostasis is a most unusual complication. Possibly in such clinical circumstances dextrans have a beneficial effect in preventing microvascular occlusion which would represent more of a hazard than impaired coagulation. There appears to be little reason to suggest preferential use of plasma since clinically overt bleeding disorders are so unusual during dextran treatment and resolve rapidly if the dextran is withdrawn. Nevertheless it is worth emphasizing that laboratory evidence characteristic of a defibrination syndrome may accompany or follow the administration of dextran. Two of the four children who had received intravenous dextran developed clinical bleeding and two did not. It is not clear precisely what determined which children bled. The cause, nature, and extent of the burn was similar in all four children, as was the order of disturbance affecting haemostasis. In burned subjects receiving dextran who develop clinical bleeding, coupled with evidence of a generalized disorder of coagulation and a fall in the platelet count, withdrawal of dextran may be the most appropriate therapeutic step.

We wish to express our gratitude to $\mathrm{Mr}$ I. W. Broomhead and Dr L. Stimmler for permission to include details about patients under their care; also to Dr M. Worby and Dr D. Briggs, house officers caring for the patients, for assistance in obtaining blood samples. We are indebted also to Dr P. Black for referring us to appropriate sources in the literature. We are particularly grateful to $\mathrm{Dr} P$. Barkhan for his advice in compiling this paper.

\section{References}

Arturson, G., and Wallenius, G. (1964). Hypercoagulability of blood after burn trauma in rats. Acta chir. scand., 128, 340-345.

Bennett, P. N., Dhall, D. P., McKenzie, F. N., and Matheson, N. A. (1966). Effects of dextran infusion on the adhesiveness of human blood-platelets. Lancet, 2, 1001-1003.

Bergentz, S. E., Eiken, O., and Nilsson, I. M. (1961). The effect of dextran of various molecular weight on the coagulation in dogs. Thrombos. Diathes. haemorrh. (Stuttg.), 6, 15-24.
Berman, H. J. (1964). Platelet agglutinability as a factor in haemostasis Bibl. anat. (Basel), 4, 736-743.

Biggs, R., and MacFarlane, R. G. (1962). Human Blood Coagulation and Its Disorders, 3rd ed. Blackwell, Oxford.

Bygdeman, S., and Eliasson, R. (1966). Effect of dextrans in vitro on the adenosine diphosphate induced adhesiveness of human blood platelets. Thrombos. Diathes. haemorrh. (Stuttg.), 15, 436-441.

Dhall, D. P., Harper, D. R., McKenzie, F. N., and Matheson, N. A (1966). Aggregation of human platelets. Nature (Lond.), 210, 745-746.

Hardisty, R. M., and Ingram, G. I. C. (1965). Bleeding Disorders. Investigation and Management. Blackwell, Oxford.

Hawtof, D. B. (1966). Intracranial hemorrhage in burned patients: report of four cases. J. Trauma, 6, 503-506.

Jacobaeus, U. (1955). The effect of dextran on the coagulation of blood. Acta med. scand., 151, 505-507.

Johansson, S. A. (1961). Heparin and thrombocytopenia in experimental burn injuries. Acta physiol. scand., 53, 239-246.

Johansson, S. A. (1964). Heparin and some coagulation factors in experimental burn injuries. Acta chir. scand., 128, 346-349.

Laurell, A. B. (1951). Influence of dextran on the conversion of fibrinogen to fibrin. Scand. J. clin. Lab. Invest., 3, 262-266.

MacDonald, A. H., Levenson, S. M., Davidson, C. S., Tagnon, H. J., and Taylor, F. H. L. (1944). Studies on the peripheral blood in $\omega$ patients with thermal burns. I. Thrombocytopenia. Science, 99, 519.

Mazák, J., Vaňásek, J., and Matěja, F. (1965). Changes in blood clotting and fibrinolysis in burnt dogs and the effects of dextran. Acta chir. plast., 7, 257-264.

Nilsson, I. M., and Eiken, O. (1964). Further studies on the effect of dextran of various molecular weight on the coagulation mechanism. Thrombos. Diathes, haemorrh. (Stuttg.), 11, 38-50.

Pitney, W. R. (1971). Disseminated intravascular coagulation. Sem. Haemat., 8, 65-83.

Sevitt, S. (1957). Burns. Pathology and Therapeutic Implications. Butterworth, London.

Symposium on Burns (1968). Early treatment of severe burns. Ann. N.Y. Acad. Sci., 150, 469-1012

Wilson, I. D., Taylor, D. R., and Nicholson, T. C. (1965). Changes in blood coagulability in dogs following flash burns. J. Trauma, $5,775-781$.

\section{Addendum}

\section{FLUID REGIME}

The amount of fluid required in the first 48 hours is estimated by comparing the percentage of body surface burned with the volume of fluid (the percentage of total fluid volume expressed in litres, assuming body weight in $\mathrm{kg}=$ litres) in the following table.

\begin{tabular}{ll}
\hline Percentage of Body Surface Burned & Percentage of Fluid Replacemen \\
\hline $10-15$ & $5-7$ \\
$15-20$ & $10-15$ \\
$20-30$ & $15-20$ \\
$30-50$ & $20-30$ \\
Over 50 & 30 \\
\hline
\end{tabular}

\section{ADMINISTRATION}

This volume is given as half colloid (dextran or $\stackrel{\mathcal{D}}{?}$ plasma) and half electrolyte (half-strength Hartman's solution) in three periods:

$\begin{array}{lll}\text { Period I ... } & \ldots & \text { One third in eight hours } \\ \text { Period II .. } & \ldots & \text { One third in 16 hours } \\ \text { Period III } & \ldots & \text { One third in } 24 \text { hours }\end{array}$


TREATMENT OF CASE 1

Body weight, $15 \mathrm{~kg}$; percentage of body surface burned 25 ; fluid replacement $=20 \%$ of 15 litres to which add basal requirements $1000 \mathrm{ml}$ per 24 hours. Colloid infusion in period I $500 \mathrm{ml}$ plasma, in period II $800 \mathrm{ml}$ Dextran $150^{1}$, and in period III $1000 \mathrm{ml}$ Dextran 110.

${ }^{1}$ Dextran 150 was used only in case 1 . In the other subjects only Dextran 110 was employed.

\section{The May 1972 Issue}

\section{THE MAY 1972 ISSUE CONTAINS THE FOLLOWING PAPERS}

Renal hyalin. A study of amyloidosis and diabetic fibrinous vasculosis with new staining methods A. C. LENDRUM, W. SLIDDERS, AND D. S. FRASER

Xanthogranulomatous pyelonephritis. A comparison of the disease in the cat and man with special reference to the origin of the fat G. B. D. SCOTT AND P. J. QUIGLEY

Australia antigen and antibody in British patients with leprosy TIN SHWE AND A. J. ZUCKERMAN

Cytoplasmic particles in hepatocytes of patients with Australia antigen-positive liver disease MARGARET E. HAYNES, DAVID W. G. HAYNES, AND ROGER WILLIAMS

Studies on the prekallikrein-bradykininogen system in liver disease DAVID STEWART, LAURENCE $M$. BLENDIS, AND ROGER WILLIAMS

Electrophoretic separation and differentiation of enzymes from human and from porcine liver D. N. BARON AND J. E. BUTTERY

An original approach to the diagnosis of scolineinduced apnoea A. FISHTAL, R. T. EVANS, AND C. N. CHAPMAN

Effect in vitro on platelet function of two compounds developed from the pyramido-pyrimidines S. D. SLATER, A. G. G. TURPIE, A. S. DOUGLAS, AND G. P. MCNICOL

Cross-reacting material in genetic variants of haemophilia B DOMINIQUE MEYER, ETHEL BIDWELL, AND MARIE JOSÉ LARRIEU

A comparison of the absorbed fluorescent treponemal antibody (FTA-ABS) test and other screening tests for treponemal disease in patients attending a venereal disease clinic A. E. WILKINSON, G. SCRIMGEOUR, AND P. RODIN
Observations on interactions between fluoresceiniso-thiocyanate conjugates and cells in vitro $\mathbf{G}$. SANDER AND J. P. JACOBS

Virological studies of sudden, unexplained infant deaths in Glasgow 1967-70 G. E. D. URQUHART AND N. R. GRIST

Antibacterial activity of nifuratel in urine and serum J. MCGEACHIE, G. ROBINSON, AND D. BLACK

\section{Technical methods}

A solid medium for visual demonstration of coagulase production by Staphylococcus aureus J. C. M. VAN DER VIJVER, C. A. KRAAYEVELD, AND M. F. MICHEL

Lysis of red cells from haematological disorders N. STATHAKIS, G. ARAPAKIS, K. KIRKOU, AND C. GARDIKAS

Estimation of serum and urinary muramidase with the eel aggregometer J. P. HAYES

Conversion of the Braun Unita I and perfusor to disposable syringes for continuous intravenous heparin infusion D. M. RAMSAY

\section{Present day practice}

False positive results with a rapid solubility test for haemoglobin $S$ J. S. LILLEYMAN, T. BILLS, AND R. J. GUYER

\section{Letters to the Editor}

Book reviews

Copies are still available and may be obtained from the PUBLISHING MANAGER, BRITISH MEDICAL ASSOCIATION, TAVISTOCK SQUARE, WC1H 9JR price $£ 1.05$ 